\title{
Brownea ariza (Rose von Venezuela)
}

Die Gattung Brownea (Fabaceae) umfasst knapp 30 Arten, die im nördlichen Südamerika (Kolumbien, Ekuador und Venezuela) und auf den Karibischen Inseln heimisch sind. Als Vertreter der Unterfamilie Caeasalpinioideae ist Brownea mit dem als Nutzpflanze bekannten Johannisbrotbaum (Ceratonia siliqua) näher verwandt. Der Gattungsname Brownea ehrt den irischen Arzt und Botaniker PATRICK BRowne. Verschiedene Brownea-Arten werden als Rose von Venezuela bezeichnet.

Der kleine Baum fällt durch seine leuchtend roten Blütenbälle auf, wodurch besonders Nektar suchende Vögel angelockt werden. Die großen, auffälligen Blüten sind radiärsymmetrisch, zwittrig und fünfzählig. Aber auch seine jungen, schlaffen und bisweilen rot-violett gefärb- ten jungen Blatt-Triebe (Laubschütte), die im Tropicarium häufig anzutreffen sind, sind sehr auffällig. Die jungen Triebe entfalten sich so schnell, dass die Bildung von Festigungsgewebe sowie von Chlorophyll nicht mit der Blattentfaltung mitkommt. Sie sind deshalb schlaff und wirken rötlich, weil die Anthocyane nicht durch Blattgrün überdeckt werden. Fressfeinde haben kein Interesse an vermeintlich welken, nicht grünen Blättern. Das Phänomen der Laubschütte zeigen auch die tropischen Nutzpfanzen Kakao und Zimtbaum.

Brownea ariza ist im Regenwald des Tropicariums zu finden.

Abb. 1: Brownea ariza im Palmengarten gleichzeitig mit Blütenstand und Laubschütte.

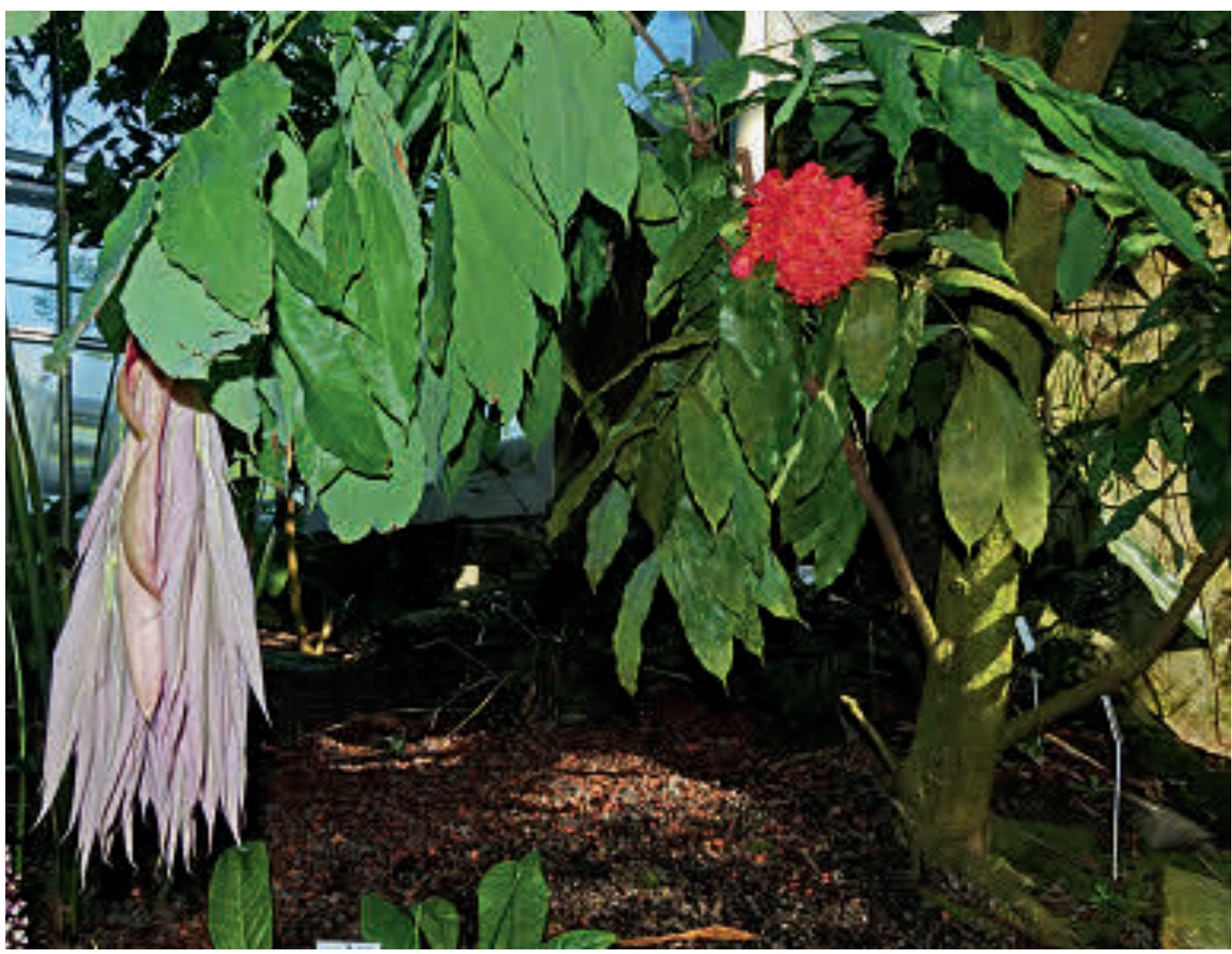

